\title{
연구노트
}

\author{
솣 제조시설의 악취물질 배출특성과 관리실태 조사 연구 \\ 정주영 · 서병량 · 김재혁 · 진성민 ${ }^{1)} \cdot$ 정종수 $)^{*}$ \\ 한국환경공단 악취관리센터, ${ }^{1}$ 한국과학기술연구원 환경복지연구단 \\ (2012년 6월 12일 접수; 2012년 7월 4일 수정; 2012년 7월 18일 채택)
}

\section{Evaluation of Malodor Release and Control Devices in Charcoal Manufacturing Facility}

\author{
Ju-Young Jeong, Byeong-Ryang Seo, Jae-Hyuck Kim, \\ Sung-Min Chin ${ }^{1)}$, Jong-Soo Jurng ${ }^{1{ }^{*}}$ \\ Korea Environment Corporation, Center for Odor Control, Daejeon 302-120, Korea \\ ${ }^{1)}$ Center for Environment Health and Welfare Research, Korea Institute of Science and Technology, \\ Seoul 136-791, Korea \\ (Manuscript received 12 June, 2012; revised 4 July, 2012; accepted 18 July, 2012)
}

\begin{abstract}
Emission characteristics of gaseous odor compounds emitted from the charcoal manufacturing process were investigated, and evaluated the odor removal efficiency of odor control devices. It was found that the measured odor dilution ratio of emission gases ranged from 10,000 to 44,814, which exceed largely the emission standard in the stack. Methylmercaptan, trimethylamine, hydrogen sulfide, acetaldehyde were turned out as major odor compounds of the charcoal manufacturing process. It was revealed that the odor removal ratio of odor control devices were very low due to the its improper maintenance and wrong design.
\end{abstract}

Key Words : Odor, Charcoal, Odor control device, Oak tree

\section{1. 서 론}

경제발전에 따른 국민의 삶의 질 향상으로 보다 쾌 적한 주거환경에 대한 욕구가 점점 증가함에 따라 다 양한 산업시설에서 발생되는 악취로 인한 민원이 급 격히 증가하는 추세이다. 2011년도 전국의 악취 민원 건수는 총 8,372건으로 조사되어 소음공해와 함께 대 표적인 생활 공해로 인식되고 있고, 특히 최근에는 음

\footnotetext{
${ }^{*}$ Corresponding author : Jong-Soo Jurng, Center for Environment Health and Welfare Research, Korea Institute of Science and Technology, Seoul 136-791, Korea Phone: +82-2-958-5688

E-mail: jongsoo@kist.re.kr
}

식점, 솣 제조시설 등 주거지와 매우 근접한 생활악취 유발시설에 대한 사회적 관심이 증가되고 있다(환경 부, 2012). 국내 솣 제조시설은 약 390개 정도로 과거 에는 주로 산속에 위치하여 단순히 숯 제조만을 목적 으로 하였으나, 최근에는 솣 제조와 함께 찜질방 운영 을 목적으로 주거지 인근에 위치하면서 숯 제조과정 에서 배기가스가 확산되어 지역 주민의 악취 민원이 증가되고 있다(서 등, 2010).

솣 제조방법은 솣가마에 참나무를 장입하고 투입 구를 밀폐시킨 후 착화시키면 참나무의 탄화가 서서 히 이루어져 숯이 제조된다. 일반적으로 솣 제조는 약 7일 정도 소요되며, 투입구의 개방여부에 따라 백탄 
및 흑탄(검탄)으로 구분된다. 백탄은 탄화가 거의 종 료될 때 투입구를 개방하면 공기가 유입되어 직접연 소에 의해 가마 내부 온도가 약 $1,200 \sim 1,300^{\circ} \mathrm{C}$ 까지 급격하게 상승되는데 이러한 조건에서 백탄이 생산된 다. 흑탄의 경우는 투입구를 개방하지 않고 저 산소 상 태를 계속 유지시켜 제조한다. 또한 숯 제조는 착화방 식에 따라 솣가마 입구 상부에 화염을 직접 공급하는 재래식(직화식)과 솣가마 측면 하부에 열기를 공급하 는 개량식으로 구분된다(박 등, 2009).

숯 제조시설은 공정 특성상 양질의 숯 생산과 생산 량 증대를 위하여 외부공기 유입을 최소화가 필요하 지만, 숯 제조과정에서 백색의 연기에는 다양한 종류 의 대기오염물질들이 배출되고 있어 대기환경보전법 에서는 용적이 $30 \mathrm{~m}^{3}$ 이상인 탄화시설을 대상으로 대 기배출시설로 관리되고 있다(서 등, 2010). 그러나 국 내 악취방지법에서는 숯 제조시설이 악취배출시설로 포함되어 있지 않고, 비규제 대상시설로 분류되어 있 어 솣 제조시설의 악취오염 규제가 현실적으로 어려 운 실정이다.

이에 본 연구는 국내 솣 제조시설을 대상으로 악취 물질의 발생 특성과 주요 원인물질 규명 및 방지시설 관리실태 등의 조사를 통해 향후 솣 제조시설의 적절 한 관리방안 마련을 위한 기초 자료를 제공하는데 목 적이 있다.

\section{2. 재료 및 방법}

\section{1. 조사 대상시설 및 내용}

본 연구는 국내 숯 제조시설 10 개소를 대상으로
2009년 8월 15일부터 2009년 9월 10일까지 악취측정 과 현장조사를 실시하였다. 지역은 경기도 6 곳, 강원 도 2 곳, 충북 2 곳이고, 대부분의 사업장에서 숯 제조 원료로 주로 참나무를 사용하고 있으며, 숯의 제조가 완료된 가마의 여열을 이용하여 대부분 찜질방을 운 영하는 것으로 조사되었다. 숯 제조과정 중 발생되는 가스를 배출시키는 과정에서 가스온도 하강에 의해 덕트에 응축되는 액체(목초액)는 판매를 위해 별도로 수집하고 있다. Fig. 1 은 일반적인 솣 제조과정을 나타 낸 것이다. 또한 조사대상 시설 모두 악취 및 대기오염 물질을 제거하기 위한 방지시설을 설치하고 있는 것 으로 나타났다.

솣가마 배기가스 덕트에서 악취측정을 통해 악취 방지법에서 정하는 복합악취 희석배수 및 각 지정악 취물질의 농도를 정량하였다. 또한 지정악취 물질별 평균농도와 최소감지농도를 고려하여 각각의 물질별 복합악취 기여율을 산정하였다. 악취방지시설의 유 입.유출구에서 동시 측정을 실시하여 방지시설의 악 취제거 성능을 조사하였으며, 현장조사를 통해 관리 실태 등을 평가하였다.

\section{2. 시료채취 방법}

솣가마 배기가스 덕트와 최종배출구인 악취방지시 설 후단의 시료 채취구에 채취관을 삽입하고, 흡입펌 프에 의해 시료를 동시 흡인하여 채취하였다.

복합악취 측정용 시료는 진공흡인상자를 이용한 간 접흡인 방식으로 폴리에스터 알루미늄 봉투(Polyester aluminum bag)에 채취하였다. 시료채취 봉투는 모든 시료에 대해 신품을 사용하였고, 시료 채취 전에 고순

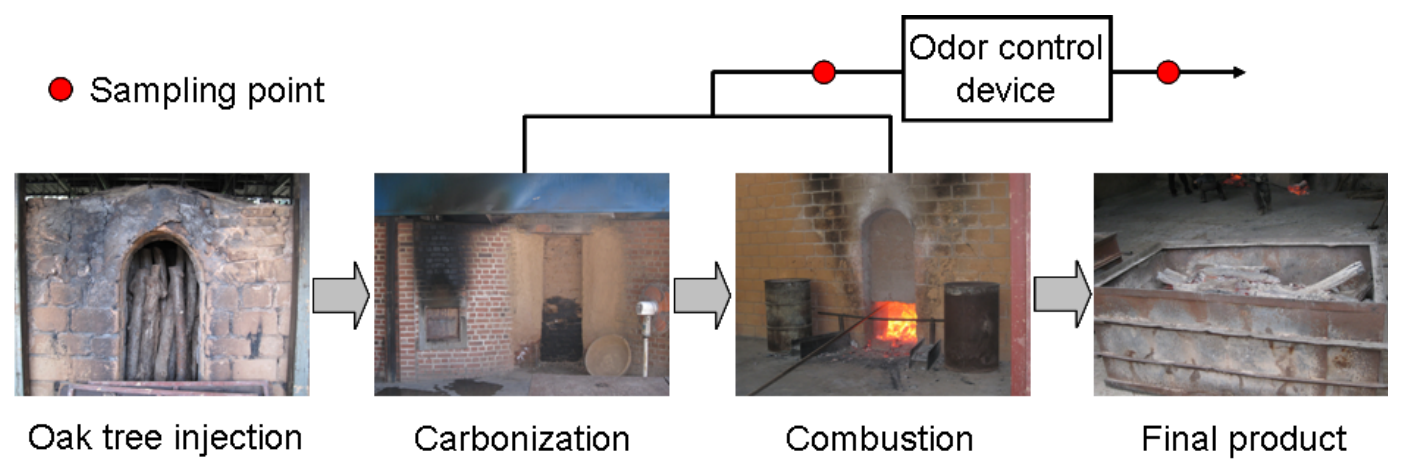

Fig. 1. Charcoal manufacturing process using an oak tree. 
도 질소로 3 회 이상 세척하고, 잔류냄새의 유무와 누 출 여부를 확인 후 사용하였다. 채취된 시료는 직사광 선을 피하여 저온상태로 보관하여 운반하였으며, 시 료채취 후 24 시간 이내에 분석을 수행하였다. 알데하 이드 및 VOCs 물질은 우선 알루미늄 봉투에 시료를 채운 후 현장에서 각 물질별로 흡인펌프를 이용해 채 취하였다.

암모니아는 2 개의 임핀져에 $0.5 \%$ 붕산흡수액을 각 각 $20 \mathrm{~mL}$ 씩 채우고, 직렬로 연결한 후 진공펌프를 이 용하여 $10 \mathrm{~L} / \mathrm{min}$ 유량으로 5 분간 채취하였다. 시료 채 취가 완료된 시료는 분석 전까지 밀봉하여 냉장 보관 하였다. 트리메틸아민은 2 개의 임핀져에 $1 \mathrm{~N}$ 황산용 액을 각각 $20 \mathrm{~mL}$ 씩 채우고, 직렬로 연결 후 $10 \mathrm{~L} / \mathrm{min}$ 유량으로 5 분간 $50 \mathrm{~L}$ 의 시료를 흡수시켰다. 황화합물 은 복합악취 측정용 시료와 동일한 방법으로 채취하 였다. 알데하이드 물질은 2,4-디니트로페닐히드라존 (이하 DNPH라 함) 유도체를 형성시키기 위해 DNPH 카트리지에 포집을 실시하였다. 현장에서 알데하이드 류 채취 시 오존이 존재하면 DNPH 유도체가 감소되 거나, 오존과 DNPH가 반응하여 인위적인 불순물이 형성될 수 있다(황 등, 1996; Slemer, 1991). 따라서 시 료 채취 시 DNPH 카트리지 앞에 오존 스크러버를 장 착하고, 적산유량계를 이용하여 $1.0 \mathrm{~L} / \mathrm{min}$ 의 유량으 로 20 분 동안 채취하였다. 휘발성유기화합물질 (VOCs)은 Tenax-TA 흡착제가 충진되어 있는 흡착관 (Supelco, U.S.A)을 이용하여 측정하였다. Tenax-TA 흡착관은 스테인레스 재질이며, 시료 채취 전에 흡착 제에 포함되어 있는 불순물을 제거하기 위해 $\mathrm{APK}$ 1200 tube conditioner(KNR, Korea)로 $260^{\circ} \mathrm{C}$ 에서 30 분, $300^{\circ} \mathrm{C}$ 에서 30 분, $320^{\circ} \mathrm{C}$ 에서 20 분 동안 $200 \mathrm{~mL}$ 의 고순도 질소를 이용하여 세척하였다.

배기가스 중 총탄화수소(Total Hydrocarbon, THC) 농도는 THC 측정 장비(Thermo, TVA 1000)를 이용 하여 현장에서 연속 측정하였다.

\section{3. 분석 방법}

복합악취 시료의 분석은 악취공정시험 기준의 공 기희석관능법에 의한 따라 판정 패널 선정시험에 합 격한 5 인의 패널을 선정하였다. 공기희석배율은 무취 공기 제조장치와 활성탄이 채워진 6 방 분배기를 통해
제조된 무취공기를 무취 봉지에 담고 시료를 주입하 여 단계별로 희석해가면서 패널들이 직접 평가하였 다. 전체 판정요원의 시료희석 배수 중 최대값과 최소 값을 제외한 나머지를 기하 평균하여 판정요원 전체 의 희석배수로 산정하였다.

암모니아 분석은 분석용 시료용액에 페놀-펜타시 아노 니트로실 철(II)산 나트륨 용액 $5 \mathrm{~mL}$ 와 차아염 소산 나트륨 용액 $5 \mathrm{~mL}$ 를 가하고, $25 \sim 30^{\circ} \mathrm{C}$ 의 수욕조 에서 1 시간 방치 후 암모늄 이온과 반응시켜 생성되는 인도페놀류의 흡광도를 측정하는 인도페놀법을 이용 하였다. 분석은 UV/vis(Varian, Cary 300, U.S.A)를 이용하여 $640 \mathrm{~nm}$ 파장에서 분석하였다. 트리메틸아 민의 분석은 분석용 시료용액을 넣은 바이알에 $50 \%$ $\mathrm{NaOH} 5 \mathrm{~mL}$ 를 가하고 전처리 장비인 Headspace (Perkinelmer, TurboMatrix 40, U.S.A)를 이용하여 혼 합(10분) 및 가압(3분) 후 바이알 상층부 기체층으로 트라이메틸아민이 용출되면 이를 가스크로마토그래피 (GC/FID)로 주입하여 분석하였다. 황화합물은 Thermal desorber(Markers, Unity/Air Server, U.S.A)를 이용 하여 농축하였으며, 농축된 시료는 황화합물에 선택 성이 좋은 불꽃광도검출기(FPD)가 설치된 $\mathrm{GC}(\mathrm{Shimadzu}$, 2010, Japan)를 사용하여 분석하였다. 2,4-DNPH 카 트리지에 채취된 알데하이드류를 용매인 Acetonitrile $5 \mathrm{~mL}$ 를 사용하여 매우 느린 속도 $(1 \mathrm{~mL} / \mathrm{min})$ 로 추출 하였다. 알데하이드류 분석은 카보닐화합물과 DNPH 와의 반응에 의해 생성된 DNPH 유도체는 자외선 영 역에서 흡광성이 있고 $350 \sim 380 \mathrm{~nm}$ 에서 최대의 감도 를 나타냄으로 UV 검출기를 이용하였고, $360 \mathrm{~nm}$ 의 파장에 고정시킨 후 HPLC(Dionex, Untimate 300, U.S.A)로 분석하였다. VOCs의 분석은 Tenax-TA 흡 착튜브를 열탈착 장치에서 고온탈착시켜 $\mathrm{GC} / \mathrm{MSD}$ (Perkinelmer, Clarus 500, U.S.A)에서 분석하였다.

\section{3. 결과 및 고찰}

\section{1. 숯 제조과정의 악취물질 배출특성}

국내 10 개 솣 제조시설에서 솣가마 배출가스(악취방 지시설 유입 전)의 악취물질 측정결과를 Table 1 에 나 타냈다. 우선 복합악취 희석배수를 살펴보면 10,000 44,814 배의 범위이고, 평균은 약 36,481 배였다. 이는 
조사대상 사업장이 위치한 지역의 악취배출허용기준 인 500 배를 72 배 초과하는 수준으로 매우 높은 것으 로 나타났다. 사업장별 복합악취 희석배수의 차이는 약 4 배 정도로 이는 솣의 제조방법 및 제조시간에 따 른 측정시점의 차이에 기인된 것으로 판단된다.

지정악취물질의 측정결과를 살펴보면 조사된 대부 분의 악취물질이 검출되는 것으로 나타났다. 악취물 질별 평균농도는 암모니아 $\left(\mathrm{NH}_{3}\right) 0.43 \mathrm{ppm}$, 트리메틸 아민 (TMA) $0.14 \mathrm{ppm}$, 황화수소 $\left(\mathrm{H}_{2} \mathrm{~S}\right) 1.25 \mathrm{ppm}$, 메 틸머캅탄(MM) $1.92 \mathrm{ppm}$, 디메틸설파이드(DMS) 0.65 $\mathrm{ppm}$, 디메틸다이설파이드(DMDS) $0.05 \mathrm{ppm}$, 아세트 알데하이드 $1.59 \mathrm{ppm}$, 프로피온알데하이드 $0.57 \mathrm{ppm}$, 뷰틸알데하이드 $0.03 \mathrm{ppm}, \mathrm{n}$-발레르알데하이드 0.00 $\mathrm{ppm}$, i-발레르알데하이드 $0.04 \mathrm{ppm}$, 메틸에틸케톤 (MEK) $2.16 \mathrm{ppm}$, 메틸이소뷰틸케톤(MIBK) 0.43 $\mathrm{ppm}$, 톨루엔 $1.51 \mathrm{ppm}, \mathrm{n}$-뷰틸아세테이트 $0.07 \mathrm{ppm}$, 스타이렌 $0.74 \mathrm{ppm}$, 자일렌 $2.01 \mathrm{ppm}$ 으로 나타났다. 현재 솣의 제조과정에서 지정악취물질이 생성되는 구 체적인 발생 메커니즘 규명에 대한 연구 결과는 보고
되고 있지 않고, 다만 나무의 구성성분 중 탄소, 질소 및 황성분이 열분해되는 과정에서 합성되는 것으로 추정된다. 또한 지정악취물질뿐만 아니라 매우 다양 한 탄화수소 계열 물질이 발생될 것으로 추정된다. Fitzer 등(1995)은 숯의 주요 구성 성분이 탄화수소, 황, 질소, 물 및 산소와 같이 다양한 유기·무기 미량 원 소로 구성되어 있는 것으로 보고하고 있다.

$\mathrm{THC}$ 평균농도는 약 $3,500 \mathrm{ppm}$ 정도로 조사되었 고, 사업장에 따라서는 $10,000 \mathrm{ppm}$ 을 초과하는 것으 로 나타났다. 숯 제조시설에서 $\mathrm{THC}$ 농도가 높은 이유 는 참나무의 리그닌과 셀룰로오스 성분이 탄화되면서 매우 다양한 탄화수소 성분이 배출되기 때문으로 판 단된다.

\section{2. 주요 악취원인물질}

숮 제조시설 배기가스의 악취원인물질을 파악하기 위해 지정악취물질별 복합악취 기여도를 평가하였다. 사람의 후각으로 감지할 수 있는 농도는 악취물질별 로 다르기 때문에 악취에 기여하는 정도를 단순히 검

Table 1. The concentration of odor compounds emitted from charcoal manufacturing process(Unit: ppm, dilution ratio)

\begin{tabular}{|c|c|c|c|c|c|c|c|c|c|c|c|}
\hline $\begin{array}{l}\text { Facilities } \\
\text { Odor compounds }\end{array}$ & A & B & $\mathrm{C}$ & $\mathrm{D}$ & E & $\mathrm{F}$ & G & $\mathrm{H}$ & I & $\mathrm{J}$ & Average \\
\hline Dilution ratio & 30,000 & 30,000 & 30,000 & 30,000 & 44,814 & 10,000 & 30,000 & 30,000 & 100,000 & 30,000 & 36,481 \\
\hline $\mathrm{NH}_{3}$ & 0.20 & 0.50 & 0.30 & 0.10 & 0.80 & 0.30 & 0.40 & 0.20 & 0.70 & 0.80 & 0.43 \\
\hline TMA & 0.77 & 0.02 & 0.02 & 0.06 & 0.25 & 0.03 & 0.18 & 0.03 & 0.06 & 0.03 & 0.14 \\
\hline $\mathrm{H}_{2} \mathrm{~S}$ & 4.35 & 0.00 & 0.00 & 0.00 & 3.48 & 0.01 & 0.88 & 1.52 & 0.63 & 1.61 & 1.25 \\
\hline MM & 8.53 & 0.09 & 0.05 & 0.01 & 5.99 & 0.01 & 1.54 & 2.34 & 0.50 & 0.13 & 1.92 \\
\hline DMS & 2.53 & 0.08 & 0.06 & 0.37 & 2.06 & 0.00 & 0.37 & 0.68 & 0.18 & 0.14 & 0.65 \\
\hline DMDS & 0.18 & 0.02 & 0.01 & 0.03 & 0.09 & 0.01 & 0.05 & 0.03 & 0.09 & 0.03 & 0.05 \\
\hline Acetaldehyde & 3.32 & 0.04 & 0.04 & 2.83 & 0.07 & 0.26 & 3.23 & 4.93 & 1.12 & 0.07 & 1.59 \\
\hline Propionaldehyde & 1.18 & 0.01 & 0.01 & 1.24 & 0.00 & 0.03 & 1.44 & 1.80 & 0.01 & 0.00 & 0.57 \\
\hline Butylraldehyde & 0.004 & 0.01 & 0.02 & 0.00 & 0.20 & 0.07 & 0.001 & 0.00 & 0.00 & 0.04 & 0.03 \\
\hline n-Valeraldehyde & 0.00 & 0.00 & 0.00 & 0.00 & 0.00 & 0.00 & 0.00 & 0.00 & 0.00 & 0.00 & 0.00 \\
\hline i-Valeraldehyde & 0.09 & 0.005 & 0.00 & 0.06 & 0.02 & 0.05 & 0.11 & 0.04 & 0.01 & 0.03 & 0.04 \\
\hline MEK & 3.09 & 2.97 & 1.54 & 2.34 & 1.78 & 1.82 & 1.39 & 1.70 & 1.94 & 3.02 & 2.16 \\
\hline MIBK & 1.26 & 0.02 & 0.02 & 0.61 & 1.16 & 0.01 & 0.52 & 0.63 & 0.06 & 0.04 & 0.43 \\
\hline Toluene & 2.21 & 1.27 & 1.16 & 1.55 & 1.89 & 0.66 & 1.57 & 1.65 & 1.63 & 1.47 & 1.51 \\
\hline n-Butylacetate & 0.03 & 0.06 & 0.10 & 0.00 & 0.23 & 0.01 & 0.00 & 0.00 & 0.21 & 0.11 & 0.07 \\
\hline Styrene & 1.88 & 0.06 & 0.17 & 1.24 & 0.53 & 0.07 & 1.06 & 1.33 & 0.66 & 0.39 & 0.74 \\
\hline Xylene & 4.53 & 0.23 & 0.43 & 3.07 & 2.85 & 0.17 & 3.20 & 3.30 & 1.30 & 0.98 & 2.01 \\
\hline THC & 5,000 & 2,200 & 1,250 & 1,500 & 11,000 & 240 & 3,600 & 5,000 & 1,240 & 2,200 & 3,323 \\
\hline
\end{tabular}


출된 농도로 평가할 수 없다. 따라서 악취물질의 감지 한계농도(최소감지농도)를 악취 실측농도와 연계시 켜 각 악취물질이 복합악취에 기여하는 정도로 표현 하는 것이 바람직하다(홍 등, 2006; 김, 2006). 우선 (식 1)에 의해 실측된 악취농도를 최소감지농도로 나 누어 악취물질별 이론적 복합악취 희석배수를 구한다 (허, 2003; 정, 2004; Frijters, 1978). 악취물질별 이론 적 복합악취 희석배수의 전체 합에 대한 각각의 악취 물질의 복합악취 희석배수가 차지하는 비율을 구하여 악취물질별 복합악취 기여도를 산정하였다.

이론적 복합악취 희석배수(배) $=\frac{\text { 악취물질별 실측농도 }(\mathrm{ppmv})}{\text { 최소감지농도 }(\mathrm{ppmv})}$

지정악취물질별 복합악취 기여도 산정 결과를 Table 2에 나타냈다. 전체 악취물질별 이론적 희석배 수는 38,900 배로 산정되어 실측된 복합악취 희석배 수인 36,481 배와 유사한 수준으로 나타났다. 따라서 본 산정결과만을 고려하면 숯 제조시설 배기가스로 인한 악취원인은 대부분 지정악취물질에 의해 유발된
것으로 추정된다. 악취물질별로 살펴보면 가장 높은 기여도를 나타낸 것은 메틸머캅탄으로 $70.5 \%$ 의 비율 을 나타냈고, 트라이메틸아민 $11.7 \%$, 황화수소 $11.2 \%$, 아세트알데하이드 $2.7 \%$ 순으로 나타나, 상기 4 가지 물질의 복합악취 기여율이 총 $96.1 \%$ 를 차지함 으로써 솣 제조시설의 대표적 악취원인물질로 평가되 었다. 한편 $\mathrm{MEK}$, 톨루엔, 자일렌 등은 검출 농도는 높 지만 최소감지농도가 상대적으로 높아 복합악취 기여 도가 높지 않은 것으로 판단된다.

\section{3. 악취방지시설 효율 및 운영실태 평가}

연구대상 사업장의 악취방지시설 입구 및 출구에 서 악취측정을 실시하여 방지시설의 악취 제거성능을 평가하였고, 그 결과를 Fig 2에 나타냈다. 사업장별 악 취방지시설 종류별 설치 현황을 살펴보면 흡착시설 단일설치 6곳, 세정시설과 연소시설의 복합설치 2곳, 흡착시설과 연소시설의 복합설치 1 곳, 연소시설 단일 설치 1 곳으로 나타났다. 흡착시설 설치 사업장은 주로 활성탄을 사용하였고, 연소시설은 연료로써 주로 $\mathrm{LPG}$ 를 사용하는 것으로 조사되었다.

흡착시설을 설치한 $\mathrm{A}, \mathrm{B}, \mathrm{C}, \mathrm{D}, \mathrm{G}, \mathrm{H}$ 사업장은 모

Table 2. The calculated odor contribution ratio of each odor compounds

\begin{tabular}{c|c|c|c|c}
\hline Odor compounds & $\begin{array}{c}\text { Odor threshold value } \\
(\mathrm{ppm})\end{array}$ & $\begin{array}{c}\text { Measured } \\
\text { odor concentration } \\
(\mathrm{ppm})\end{array}$ & $\begin{array}{c}\text { Theoretical } \\
\text { dilution rate }\end{array}$ & Odor contribution ratio(\%) \\
\hline \hline $\mathrm{NH}_{3}$ & 1.5 & 0.43 & 0 & 0.0 \\
\hline $\mathrm{TMA}$ & 0.000032 & 0.15 & 4,547 & 11.7 \\
\hline $\mathrm{H}_{2} \mathrm{~S}$ & 0.00041 & 1.78 & 4,348 & 71.2 \\
\hline $\mathrm{MM}$ & 0.00007 & 1.92 & 27,419 & 0.5 \\
\hline $\mathrm{DMS}$ & 0.003 & 0.65 & 216 & 0.1 \\
\hline DMDS & 0.0022 & 0.05 & 24 & 2.7 \\
\hline Acetaldehyde & 0.0015 & 1.59 & 1,061 & 0.6 \\
\hline Propionaldehyde & 0.001 & 0.64 & 636 & 0.0 \\
\hline Butylraldehyde & 0.00067 & 0.05 & 74 & 1.2 \\
\hline $\mathrm{n}$-Valeraldehyde & 0.00041 & 0.00 & 5 & 0.0 \\
\hline i-Valeraldehyde & 0.0001 & 0.05 & 561 & 0.1 \\
\hline MEK & 0.44 & 2.16 & 5 & 0.0 \\
\hline MIBK & 0.017 & 0.43 & 25 & 0.0 \\
\hline Toluene & 0.33 & 1.51 & 5 & 0.1 \\
\hline n-Butylacetate & 0.016 & 0.08 & 21 & 0.1 \\
\hline Styrene & 0.035 & 0.74 & 49 & - \\
\hline Xylene & 0.041 & 2.01 & 38,900 & \\
\hline Dilution ratio & & 36,481 & & \\
\hline
\end{tabular}




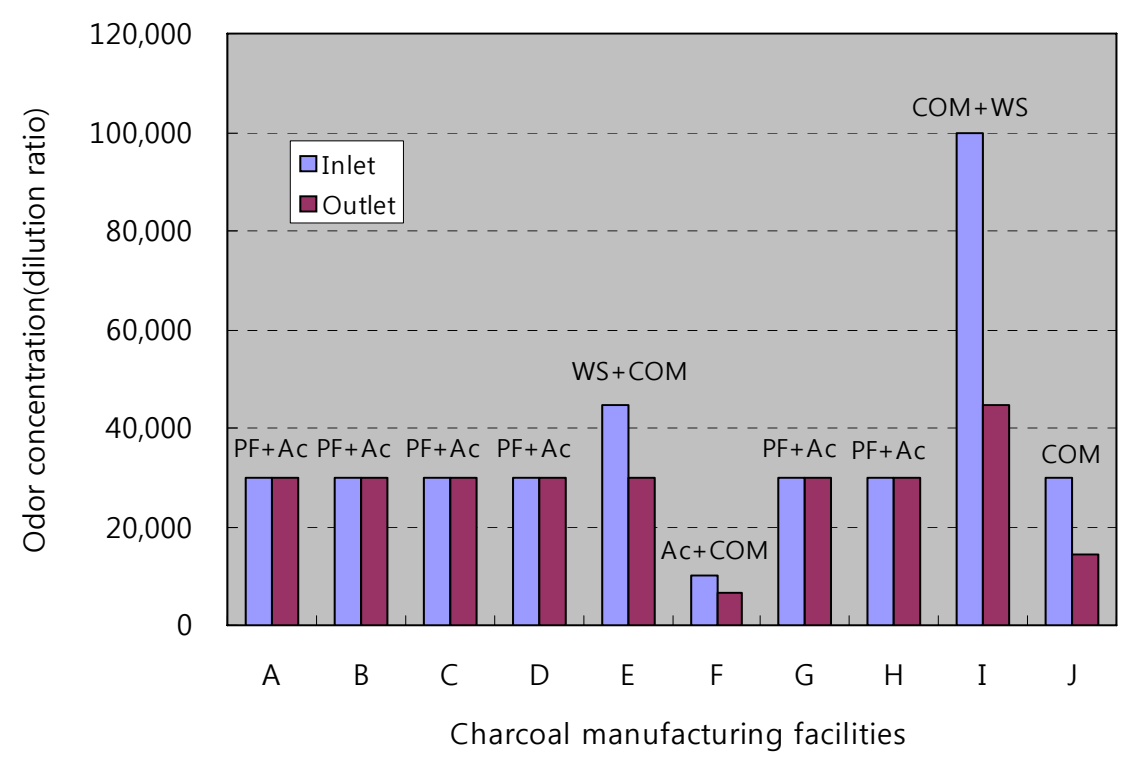

Fig. 2. Odor concentration measured in inlet and outlet of odor control device. PF :Pre-filter, Ac: Activated carbon, WS: Wet Scrubber, COM: Combustion.

두 입구와 출구의 복합악취 희석배수가 같아 악취제 거 성능이 거의 없는 것으로 나타났다. 활성탄은 휘발 성유기화합물과 같은 악취물질의 흡착 제거에 매우 효과적인 방지시설이지만, 오염물질 흡착량이 제한되 어 있어 흡착이 완료되어 파과점(Breakthrough point) 에 이르면 입구농도와 출구농도가 같아진다. 따라서 현재 조사 대상 사업장 대부분 현재 활성탄이 파과점 에 이르러 있는 것으로 판단된다. 특히 숯 제조과정에 서는 먼지, 목초액 및 점착성의 타르성분이 다량 발생 하고 있는데 이러한 성분이 활성탄 표면에 피복되면 활성탄의 흡착력이 급격히 낮아질 수 있다. 이러한 성 분들을 제거하기 위해 먼지제거 필터를 사용하는데, 필터교체가 제때 이루어지지 않아 필터 기능이 거의 상실되어 있는 상태로 나타났다. Fig. 3(left)은 목초액 및 점착성 타르에 의한 활성탄 오염실태를 나타낸 것 이다. 또한 본 조사에서 숯 제조과정의 주요 악취원인 물질이 메틸머캅탄, 황화수소, 트리메틸아민, 아세트 알데하이드 등으로 확인되었는데, 활성탄은 이들 성 분에 대한 흡착력이 상대적으로 낮은 편이다. 따라서 솣 제조시설에서 활성탄 흡착시설에 의해 높은 악취 제거율을 유지하기 위해서는 활성탄을 오염시키는 불
순물의 사전 차단과 악취원인물질을 효과적으로 흡착 할 수 있는 기능성 활성탄의 사용 및 주기적인 교체가 필수적이다.

연소시설을 설치한 곳 중 $\mathrm{E}$ 와 I 사업장은 연소시설 과 함께 세정시설이 설치되어 있고, $\mathrm{F}$ 사업장은 연소 시설과 흡착시설, $\mathrm{J}$ 사업장은 연소시설만 설치되어 있 다. 각 사업장별 복합악취 제거율을 살펴보면 E $33 \%$, $\mathrm{F} 33 \%$, I $55 \%$, J 52\%로 $33 \sim 55 \%$ 의 범위를 나타나 흡착시설과 비교해 상대적으로 높았지만, 연소법의 일반적인 악취제거율이 $99 \%$ 로 알려져 있는 점을 고 려하면 비교적 낮은 수준으로 판단된다. 그 이유는 연 소시설이 대부분 부적절하게 설계되어 불완전연소에 의해 제거효율이 낮고, 동시에 알데하이이드 등 저농 도에서도 냄새를 유발하는 중간생성물이 발생되기 때 문으로 판단된다. 악취가스의 완전연소를 위한 조건 은 3T, 즉 온도(Temperature), 체류시간(Time), 혼합 (Turbulence)를 유지되어야 한다. 악취 제거를 위해서 는 연소실 온도 $800^{\circ} \mathrm{C}$ 이상, 충분한 체류시간 0.5 초 이상, 혼합기구 등이 필요하다(石黒, 2002). 현장조사 결과 각 사업장별 연소실 체류시간은 $0.3 \sim 0.4$ 초이고, 원통형의 연소로에 버너가 설치된 단순 구조로 충분 

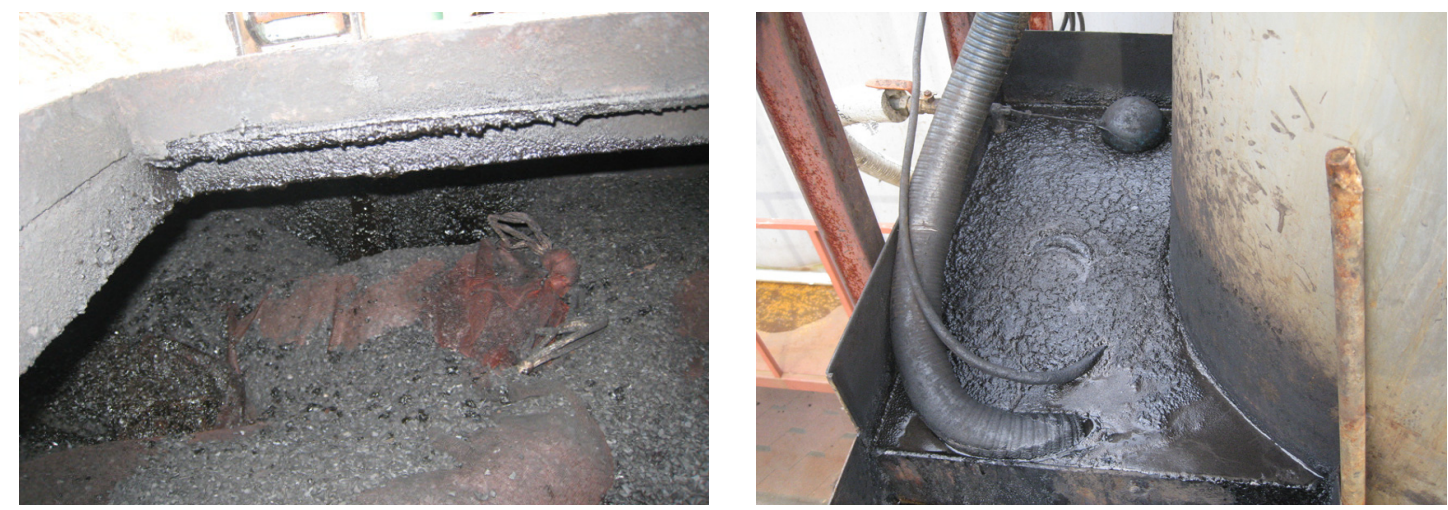

Fig. 3. Liquid tar contamination on the surface of activated carbon(left) and scrubbing water(right).

한 혼합이 어려운 구조로 나타나, 연소로 운전조건이 부적절하여 불완전연소가 발생하는 것으로 판단된다. 다만, 본 조사에서 연소시설의 내부 온도의 측정은 불 가능하였다.

$\mathrm{E}$ 와 I 사업장은 연소시설과 함께 세정시설이 설치 되어 있는데, $\mathrm{E}$ 의 경우는 전처리 시설로써 $\mathrm{I}$ 의 경우는 연소 후 배기가스의 후처리 기능을 가지고 있다. 그러 나 Fig. 3(right)은 전처리 시설로 사용된 세정시설의 순환수 상태를 나타낸 것으로 점착성 타르에 의해 심 각하게 오염되어 있고, 순환수 교체도 이루어지지 않 아 전처리 시설로의 기능이 상실된 것으로 판단된다. 또한 후처리 시설로 사용된 경우는 연소 후의 높은 배 기가스 온도 $\left(100^{\circ} \mathrm{C}\right.$ 이상 $)$ 로 인해 세정시설로써의 기 능을 기대하기 어려울 것으로 판단된다. 따라서 숯 제 조시설 악취처리를 위해 연소시설을 적용할 경우에는 완전 연소가 가능한 구조로 연소장치를 설계하는 것 이 반드시 필요하다.

\section{4. 결 론}

본 연구에서는 국내 숯 제조 사업장을 대상으로 숯 의 제조과정 중 배출되는 악취물질의 농도, 원인 물질 등의 배출특성을 분석하였고, 또한 악취방지시설의 제거효율 조사와 관리실태를 현장조사를 통해 평가하 였다. 주요 연구 결과는 다음과 같다.

1) 숯 제조과정 배출가스 중의 복합악취 희석배수 는 사업장 별로 $10,000 \sim 44,814$ 배 범위이고, 평 균 희석배수는 36,481 배로 나타났다. 이는 기타
지역 악취배출허용기준인 500 배를 크게 초과하 는 것으로 조사되었다.

2) 지정악취물질 측정농도를 바탕으로 악취물질별 기여도를 평가한 결과, 메틸머캅탄 $70.5 \%$, 트라 이메틸아민 $11.7 \%$, 황화수소 $11.2 \%$, 아세트알 데하이드 $2.7 \%$ 순으로 산정되어 숯 제조시설의 대표적 악취원인물질로 평가되었다.

3) 조사대상 사업장은 악취방지시설로 흡착시설 또 는 연소시설을 운영하는 것으로 나타났다. 흡착 시설의 악취제거 성능은 모든 사업장에서 거의 없는 것으로 나타났고, 이는 적절한 시기에 활성 탄의 교체가 이루어지지 않아 현재 파과점에 이 르렀기 때문으로 판단된다. 특히 솣 제조과정에 는 먼지, 목초액 및 점착성 타르가 다량 발생하 여 활성탄의 파과를 촉진하므로 필터 등을 이용 하여 흡착시설 유입 전에 완벽한 제거가 필요할 것으로 판단된다.

4) 연소시설의 악취제거율은 약 $30 ~ 55 \%$ 로 나타 나 비교적 낮은 수준으로 평가되었다. 그 원인은 연소시설이 대부분 부적절하게 설계되어 악취 물질이 효과적으로 분해되지 않고, 불완전연소 생성물이 배출되기 때문으로 판단된다.

\section{참 고 문 헌}

김현욱, 2006 , 악취발생원별 주요 악취 화합물 특성 및 관리지침, 한국냄새환경학회, 95-101. 박정구, 정주영, 서병량, 2009, 2009년도 악취배출사업 
장 맞춤형 기술지원 최종보고서, 한국환경공단. 서병량, 조정철, 박정구, 2010 , 숯 제조시설에서의 악취 발생 특성 및 관리방안, 정기학술발표회논문집, 한 국냄새환경학회, 93-97.

정의석, 2004, 직 · 간접 관능법을 응용한 악취평가방법 및 해석에 관한 연구, 박사학위논문, 대전대학교. 환경부, 2007, 악취공정시험방법.

환경부, 2012, 악취관리 정책방향, 2012년 악취관리 연 찬회 발표자료.

황윤정, 박상곤, 백성옥, 1996, DNPH 카트리지와 HPLC

를 이용한 대기 중 카르보닐화합물의 농도측정, 분 석방법의 평가와 실제에의 적용, 한국대기보전학회 지, 11(2), 199-209.

허귀석, 2003, 공업단지에서 배출되는 악취 원인물질의
규명, 정기학술발표회논문집, 한국냄새환경학회, 17-18. 홍길환, 차재두, 고영환, 이정훈, 임은주, 김경섭, 2006, 음식물 쓰레기 퇴비화시설의 악취배출 성상 조사, 한국냄새환경학회지, 5(3), 151-155.

石黒 辰吉, 2002, 普及版 防臭技術集成, エヌティーエ ス, 103-114.

Fitzer, E., KÖchiling, Boehm, H. P., Marsh, H., 1995, Recommended terminology for the description of carbon as a solid, Pure Appl. Chem., 67, 473-506.

Frijters, J. E. R., 1978, A critical analysis of odour unit number and its use, Chem. Senses., 3, 227-233.

Slemer, J., 1991, Determination of volatile carbonyl compounds in clean air, J. Anal. Chem., 340, 672-677. 